Article

\title{
Analysis of the Factors Influencing Market Participation among Smallholder Rice Farmers in Magway Region, Central Dry Zone of Myanmar
}

\author{
Nyein Nyein Kyaw ${ }^{1}$, Soojung Ahn ${ }^{2}$ and Sang Hyeon Lee ${ }^{3, *}$ \\ 1 Department of International Cooperation, Kangwon National University, Chuncheon 24341, Korea; \\ nyeinkyaw2@gmail.com \\ 2 Department of Agricultural, Food and Resource Economics, Michigan State University, East Lansing, \\ MI 48824-1039, USA; ahnsooju@msu.edu \\ 3 Department of Agricultural \& Resource Economics, Kangwon National University, Chuncheon 24341, Korea \\ * Correspondence: shl@kangwon.ac.kr; Tel.: +82-33-250-8662
}

Received: 8 November 2018; Accepted: 23 November 2018; Published: 27 November 2018

check for updates

\begin{abstract}
Smallholder farmers face numerous constraints that restrict their access to markets and prevent them from taking advantage of market opportunities. This research aimed to examine the factors affecting the market participation of smallholder farmers and find ways to improve the income and livelihood of smallholder farmers, focusing on Myothit Township in Magway Region, Central Dry Zone of Myanmar. For the primary data, we surveyed 150 smallholder rice farmers which were selected using a random sampling technique. Using the Heckman two-stage selection model, we analyzed the factors influencing smallholder rice farmers' decisions regarding participation in the agricultural market. This study revealed that the decision to participate in the rice market was dependent on different factors such as the household head age, education status, household size, total produce of rice, price of rice, household income, ownership of livestock, membership of farmer organization, access to roads, distance to market, access to extension services, and market information. The results of this study have implications as to what factors need to be addressed to encourage smallholder rice farmers to participate in the market. We suggest that Myanmar government and policymakers need to establish balanced policies for small-scale farmers and manage them in an appropriate way so that agricultural development can be induced, contributing to poverty reduction, food security, and economic development.
\end{abstract}

Keywords: smallholder farmers; sustainability; agricultural development; market channels; myanmar agriculture

\section{Introduction}

Market participation of farmers is both a cause and a consequence of economic development $[1,2]$. It is a major pathway for rural people in assuring better income and improving food security. The existence of markets and improved market access are important for smallholder farmers since it can draw agricultural and economic development. Improved access to markets has paramount importance in increasing smallholder market participation and the extent of their participation, ceteris paribus $[3,4]$.

Smallholder agriculture, one of the principal economic occupations in the world, is the main source of income and employment for the 70 percent of the world's poor in rural areas [5]. Smallholder farmers contribute to food security, equitable distribution of income, and linkage creation for economic growth [6]. However, smallholder farmers are facing constraints in terms of physical access to markets and lack of market information [7]. Farmers involved in traditional food crops generally depend 
on informal markets due to weak or lack of linkages with formal markets [8]. Smallholder farmers can significantly increase their incomes by enlarging the market sales ratio [9]. Nonetheless, the participation rate of smallholder farmers in the rice market remains low due to various constraints [10]. Fundamentally, most of the smallholder farmers are in remote areas with poor transport and market infrastructures, causing high transaction cost. In addition, they lack reliable market information as well as information on potential exchange partners [4]. Due to their small surpluses in production, smallholders are also generally exposed to a higher degree of risk and transaction costs [9]. Most rural farmers sell their produce mainly at their farm gate and in village markets. Their decisions on the amount of output to sell are mainly influenced by marketing information, produce prices, and distance to the market [11]. Economic liberalization has provided opportunities for smallholder farmers to diversify their products and take their surplus to nearby markets [12]. However, one drawback regarding smallholder farmers is that they lack marketing knowledge and as a result, most of the crops are sold with lower prices at their farm gate or in local markets [13]. Limited access to guaranteed markets for their produce and for the acquisition of inputs is another major problem the smallholders confront [14]. Countries with the highest portion of smallholder farmers are recognized as low-income countries [15]. In South Asia and Sub-Saharan Africa, more than $60 \%$ of the farm households have less than 1 ha of farmland, and more than $80 \%$ of the farm households have less than 2 ha of farmland [15]. Thus, it is necessary to take actions to increase economic activities of smallholder farmers so that they can raise competitiveness [16]. Myanmar, which is designated as an underdeveloped country by the UN and located in South Asia, is also largely comprised of smallholder farms [17]. 80\% of the Myanmar farms are producing rice, with a large portion of small-scale farms that do not exceed 5 ha [17]. Therefore, studying the market participation of rice farmers in Myanmar can provide useful implications for countries in similar circumstances and characteristics.

Myanmar is a typical agriculture country and possesses moderate natural resources which have underpinned the agricultural production. The population was estimated at around 51.49 million in 2016 and about 70\% of the total population in Myanmar reside in rural areas and the rural populace is principally engaged in the agriculture, livestock, and fishery sectors for their livelihood [18]. The agricultural sector is essential for the food security of the growing population and it is contributing a large part of the export earnings of the country. The agricultural sector occupies $28.6 \%$ of the GDP; $25.5 \%$ of the total export earnings; and employed $61.2 \%$ of the labor force in 2015-2016 [18]. Myanmar's total sown area was 21.32 million ha of which rice accounts for 34\% in 2015-2016 (Figure 1) [18].

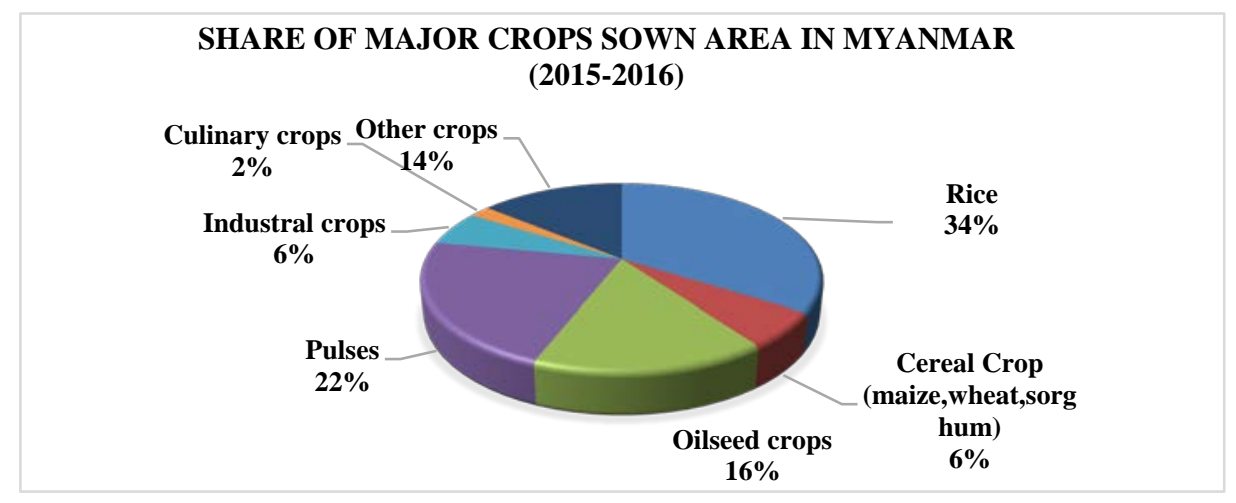

Figure 1. Share of major crops sown area in Myanmar. Source: [19].

Rice is a major crop among the cultivated crops in Myanmar and plays a crucial role in the national economy. It is not only a staple food but also a source of processed food products such as vermicelli, rice noodle, rice cake, and so forth. The total sown area of paddy was 7.21 million ha in 2015-2016 (Figure 2) [18]. About 6.22 million ha are cultivated in monsoon season and 0.99 million ha in the summer season [20]. From this evidence, we can assume that efficient rice production would 
provide more income and export revenue for the country as it occupies a large portion of agricultural production in Myanmar.

The main purpose of this study was to examine and analyze factors that affect the sale of rice by smallholder farmers in Myothit Township, Magway Region, Central Dry Zone of Myanmar. The specific objectives of the study were to investigate and analyze demographics; socioeconomic characteristics of the smallholder rice farmers in the study area; the factors affecting rice marketing; and the effect of socioeconomic and personal characteristics on the farmers' net farm incomes.

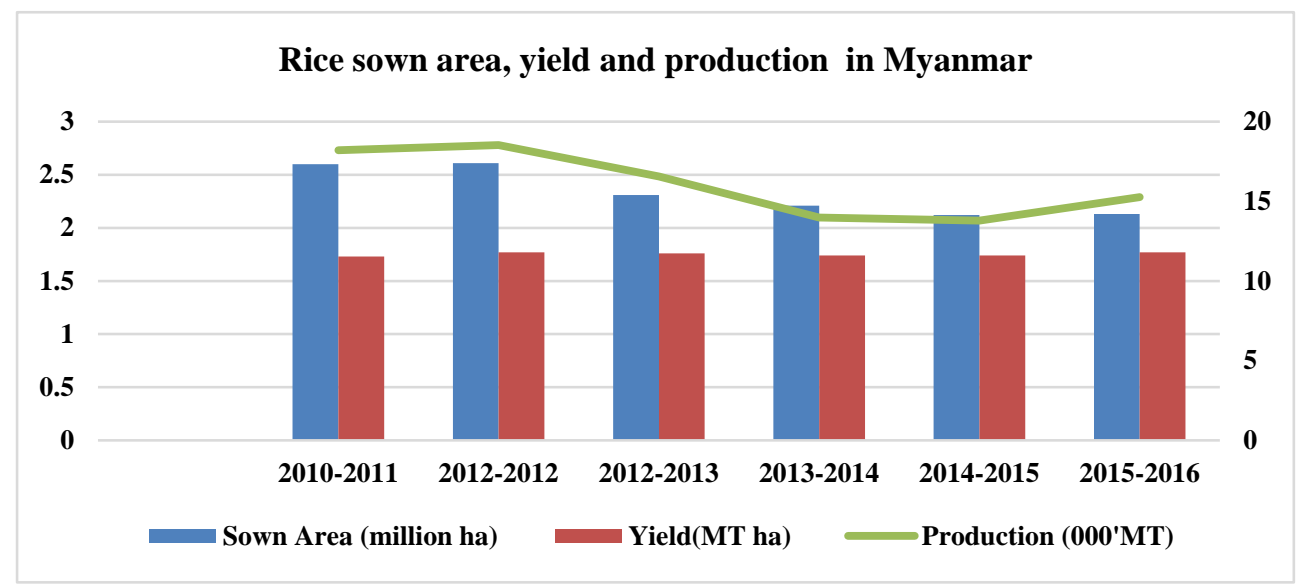

Figure 2. Rice sown area, yield, and production in Myanmar. Source: [19].

\section{Material and Methods}

\subsection{Study Area and Data Collection}

Myothit Township is in the Magway Region in the Dry Zone with a total population of 157,544 [19]. There were 47 village tracts and 169 villages in Myothit Township and rice has been grown in all village tracts. The total land area of the township is $158,677.99$ ha (612.68 sq miles) and 92,974 ha of the township are under cultivation [19]. Geographically, Myothit Township is located 300 feet above the sea level, the minimum annual temperature is $55.94^{\circ} \mathrm{F}$, the maximum annual temperature can be reached as high as $107.6^{\circ} \mathrm{F}$ and the mean annual rainfall is $811.53 \mathrm{~mm}$ [19]. We used Myothit Township as the focus area since rice production is prevalent in that township. Economic activities in Myothit Township include crop production such as rice, oilseed crop, and beans for economic purposes and commercial businesses [20]. Other minor agricultural products include maize, cotton, onion, sugarcane, and vegetables [20].

Our study used both primary and secondary sources of data. First, primary data were collected through surveys, consisting of semi-structured questionnaires answered by 150 smallholder rice farmers from three villages from March to April, in 2018, by a team of five enumerators. The data includes socioeconomic characteristics of the farmers, household characteristics, crop output, and sales. Secondary data on township land use, cropping pattern, crop yield, the township map, irrigated area, and agricultural infrastructure survey reports were collected from published and official records of Ministry of Agriculture and Irrigation (MOAI), Department of Planning [18], Department of Agriculture [20], Department of Agricultural Land Management and Statistics [19], and some other government organizations.

\subsection{Conceptual Framework}

The conceptual framework (Figure 3) illustrates the interrelationships of the key variables involved in the study and how they are interrelated. Socioeconomic characteristics are the background factors such as age, education level, household size, total produce of rice, and ownership of livestock. Institutional factors include access to extension service, access to roads, and membership of a farmer 
organization. For market factors, we observed distance to the market, prices of rice, and access to market information and all these factors had an influence on market participation. Due to the above factors, smallholder farmers participate in the rice market and the extent of that participation varies.

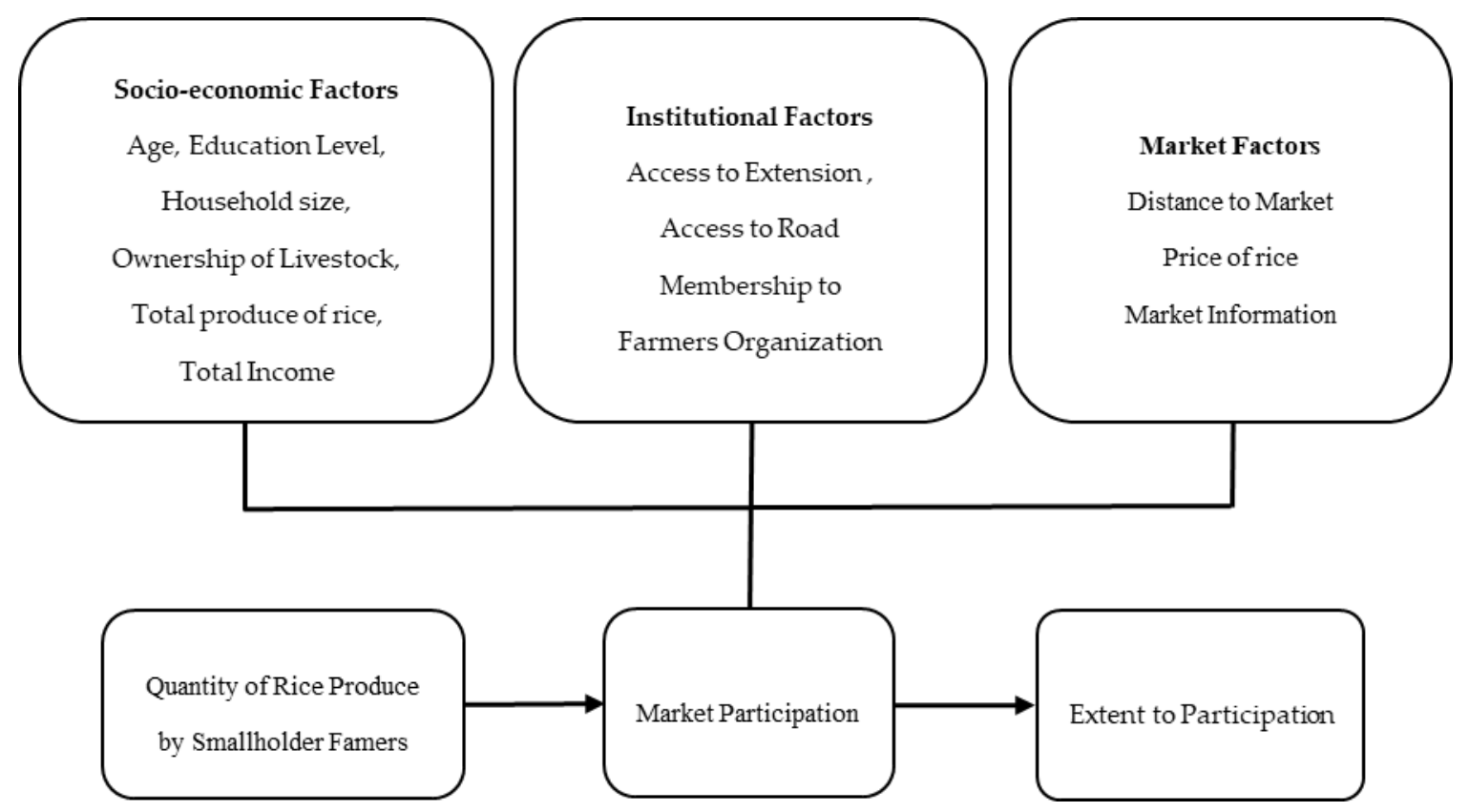

Figure 3. Conceptual framework.

\subsection{Analytical Method}

Two types of statistical methods were used to analyze the collected data. First, descriptive statistical methods such as arithmetic means, standard deviations, percentages, and standard deviations were used to describe and examine the socioeconomic characteristics of smallholder rice farmers as well as institutional and market characteristics of rice marketing in Myothit Township in Magway Region, Central Dry Zone of Myanmar.

Second, the generalized Heckman two-stage model was used for econometric analysis to determine the factors that influence whether smallholder farmers participate in the market and the extent of that participation [21]. The Heckman two-step model involved the estimation of two equations. Among the two dependent variables, the first dependent variable is whether a household participated in the rice market or not, and the second dependent variable indicates the extent of market participation (proportion of rice sales). The proportion of rice sales is conditional on market participation decisions. Therefore, there may be a systematic difference between the farmers depending on whether they participate in the market, which generates sample selection bias. The Heckman two-stage model corrects sample selection bias from non-randomly selected samples [22,23]. The generalized version of the model also reduces heteroskedastic errors [24].

The model consists of two steps; first, selection equation was estimated using a probit model. A probit model predicts the probability of whether an individual household participated in the rice market or not as shown in Equation (1).

$$
\operatorname{Pr}\left(Z_{i}=1 / W_{i}, \alpha\right)=\varnothing\left(h\left(W_{i}, \alpha\right)\right)+\varepsilon_{i}
$$

where $Z_{i}$ is an indicator variable equal to unity for smallholder rice farmers that participated in the marketing, $\varnothing$ is the standard normal cumulative distribution function, $W_{i}$ is the vector of factors affecting the decision to participate in the rice market, $\alpha$ is the vector of coefficients to be estimated, and $\varepsilon_{i}$ is the error term assumed to be distributed normally with a mean of zero and a variance $\sigma^{2}$. 
The variable $Z_{i}$ takes the value of 1 if the marginal utility the household $i$ get from participating in the rice market is greater than zero, and zero otherwise. This is shown as follows in Equation (2),

$$
\begin{aligned}
& Z_{i}=0 \text { if } Z_{n i} \leq 0 \\
& Z_{i}=1 \text { if } Z_{n i}>0
\end{aligned}
$$

where $Z_{i}^{*}$ is the latent level of utility the smallholder rice farmers get from participating in the market, and with $\mu_{i} \sim N(0,1)$,

$$
Z_{i}^{*}=\alpha w_{i}+\mu_{1 i}
$$

In the second step, an additional regressor in the sales equation will be included to correct for potential selection bias. This regressor is the inverse Mills ratio (IMR).

The IMR is computed as Equation(4):

$$
\frac{\varnothing\left(h\left(W_{i} / \tilde{a}\right)\right)}{\varnothing\left(W_{i}, \tilde{a}\right)}
$$

where $\phi$ is the normal probability density function. The second-stage equation is given by Equation (5):

$$
E=\left(Y_{i} / Z=1\right)=f\left(x_{i}, \beta\right)+\gamma \frac{\varnothing\left(h\left(W_{i} / \tilde{a}\right)\right)}{\varnothing\left(W_{i}, \tilde{a}\right)}
$$

where $E$ is the expectation operator, $Y$ is the (continuous) proportion of rice sold, $x$ is a vector of independent variables affecting the quantity of rice sold, and $\beta$ is the vector of the corresponding coefficients to be estimated. Therefore, $Y_{i}$ can be expressed as follows:

$$
Y_{i}^{*}=\beta^{\prime} X_{i}+\gamma+\mu
$$

where $\mu_{i} \sim N\left(0, \sigma_{\mu}\right) . Y_{i}^{*}$ is only observed for those rice farmers who participate in the rice market and if $Z_{i}=1, Y_{i}=Y_{i}^{*}$.

The model can thus be estimated as follows; the first step of deciding whether to participate in rice marketing or not can be specified as:

$$
P(0,1)=\beta_{0}+\beta_{1} X_{1}+\beta_{2} X_{2}+\ldots . .+\beta_{n} X_{n}+\varepsilon_{i}
$$

where participation is denoted by 1 and non-participation is denoted by $0 . \beta_{0}$ is a constant, $\beta_{1}, \ldots, \beta_{n}$ are parameters to be estimated, $X_{1}, \ldots, X_{n}$ are the vector of explanatory variables, and $\varepsilon_{i}$ is an error term.

The second step, which involves a decision on the extent of rice marketing, is estimated by OLS as follows;

$$
Y_{i}=\beta_{0}+\beta_{1} X_{1}+\beta_{2} X_{2}+\ldots \ldots+\beta_{n} X_{n}+\varepsilon_{i}
$$

where $Y_{i}$ denotes the rice sales in percentage(\%). $\beta_{0}$ is a constant, $\beta_{1}, \ldots, \beta_{n}$ are parameters to be estimated, $X_{1}, \ldots, X_{n}$ are the vector of explanatory variables and $\varepsilon_{i}$ is an error term.

The two equations for each step are specified as follows: The variables used in the Heckman two stages are shown in Table 1.

\section{Step 1. (Selection Equation)}

$$
\begin{gathered}
P(0,1)=\beta_{0}+\beta_{1} \text { Age }+\beta_{2} E d u+\beta_{3} \text { Output }+\beta_{4} \text { Ownlivestock }+\beta_{5} \text { Org } \\
+\beta_{6} \text { Road }+\beta_{7} \text { Ext }+\beta_{8} \text { Markinfo }+\varepsilon_{i}
\end{gathered}
$$




\section{Step 2. (Outcome Equation)}

$$
\begin{aligned}
& \text { Proportion of rice sales }\left(Y_{i}\right) \\
& \quad=\beta_{0}+\beta_{1} \text { Age }+\beta_{2} \text { Edu }+\beta_{3} \text { Hsize }+\beta_{4} \text { Output }+ \\
& \beta_{5} \text { Price }+\beta_{6} \text { TotalIn }+\beta_{7} \text { Ownlivestock }+\beta_{8} \text { Org }+\beta_{9} \text { Road }+ \\
& \beta_{10} \text { Distmk }+\beta_{11} \text { Ext }+\beta_{12} \text { Markinfo }+\varepsilon_{i}
\end{aligned}
$$

where Age denotes the age of household head, Edu is the education level of household head, Hsize is the household size, Output is the total production of rice, Price is the price of rice, TotalIn is the total household income. Ownlivestock is livestock ownership, Org is membership of a farmer organization, Road is access to roads, Distmk is distance to the market, Ext is access to extension service, and Markinfo

\begin{tabular}{|c|c|c|c|}
\hline Variables & Variable & Measurement of the Variables & $\begin{array}{l}\text { Expected } \\
\text { Sign }\end{array}$ \\
\hline \multicolumn{4}{|c|}{ Dependent Variables } \\
\hline Prob (Y) & $\begin{array}{c}\text { Type of household (market } \\
\text { participant/Non-market participant) }\end{array}$ & $\begin{array}{l}\text { Dummy }(1=\text { market participant, } \\
0=\text { Non-market participant })\end{array}$ & \pm \\
\hline Rice sold & Volume of rice sold in the market (\%) & Proportion of Rice sale & \pm \\
\hline \multicolumn{4}{|c|}{ Independent Variables } \\
\hline Age & Age of the household head & In Years (Continuous) & \pm \\
\hline Educ & Education level of the household head & Education Level (Continuous) & \pm \\
\hline Hsize & Household size & Size of Household (Continuous) & \pm \\
\hline Output & Total production of rice & In Kilogram & + \\
\hline Price & Price of rice & In Kyats (Continuous) & + \\
\hline TotalIn & Household income & In Kyats (Continuous) & \pm \\
\hline OwnLivestock & Ownership of livestock & Dummy $(1=$ Yes, $0=$ No $)$ & \pm \\
\hline Org & Membership to farmer organization & Dummy $(1=$ Yes, $0=$ No $)$ & \pm \\
\hline Road & Access to roads & Dummy $(1=$ Yes, 0 = No $)$ & + \\
\hline Distmkt & Distance to the market & In Kilometer (Continuous) & - \\
\hline Ext & Access to extension service & Dummy $(1=$ Yes, $0=$ No $)$ & + \\
\hline Marketinfo & Access to market information & Dummy $(1=$ Yes, $0=$ No $)$ & + \\
\hline
\end{tabular}
is the access to market information.

Table 1. Factors influencing market participation for rice smallholder farmers by using the Heckman two-stage model.

\subsection{Justification for Inclusion of Hypothesized Variables}

\subsubsection{Age of Household Head}

The age of the household head was used as a proxy measure of experience in production and marketing. The age of the household head was captured as a continuous variable. Olwandeis and Mathenge [25] found that age of the household head negatively influenced the decision to participate in the market in Kenya. Based on this evidence, age of the household head was hypothesized to have an indeterminate relationship with the probability of market participation and the decision on the amount of rice to market for smallholder farmers.

\subsubsection{Education Level of Household Head}

The education level of the household head was captured as a continuous variable, indicating the number of years spent in formal school. The education level of household head has been found to influence market participation because household heads with a high level of education may have better abilities to negotiate and to acquire more information than those with a low level of education [26]. Thus, it was assumed that the education level of household heads would have a positive impact on determining both market participation and volume of market sales among smallholder farmers. 


\subsubsection{Household Size}

The household size was used as a continuous variable indicating the number of members who directly depend on the household. The larger the household size, the smaller the market surplus because larger families require greater food consumption and the lower the potential sales of agricultural products. Martey et al. [27] found that a large household may reduce the marketable surplus to meet household consumption needs. Siziba et al. [28] found household size negatively influences the decision of farmer participation in the cereal market among cereal producers in Sub-Saharan Africa (SSA). In this regard, an indeterminate relationship between household size and the volume of rice sold to the market was hypothesized.

\subsubsection{Price of Rice}

The price of rice was included in the regression as a continuous variable (Kyats) in Myanmar currency. Farmers that received a high market price for rice produced more and increased market surplus. According to Komarek [29], it was found that output price positively influenced both the probability and intensity of market participation among banana producers in Uganda. Omiti et al. [11] found that output price had a positive impact on the intensity of market participation among maize and kale producers in peri-urban Kenya. Thus, we postulated that rice prices were a factor that positively influenced both the decision to participate in the market and the volume of rice sold to the market among smallholder farmers.

\subsubsection{Ownership of Livestock}

The ownership of livestock was used as a dummy variable, indicating if the household owned livestock. Martey et al. [27] found that ownership of livestock negatively affected participation in crop market because it disperses farmers into alternative sources of income. Livestock is an important production shifter because they enhance the capacity of a household to produce more, increasing the chances of a household's market participation [30]. In this study, an indeterminate relationship between the ownership of livestock and the probability of market participation and volume of rice sold was hypothesized.

\subsubsection{Membership in a Farmer Organization}

This variable was included as a dummy variable if any of the household members had a membership in the farmers' organization. Membership of the farmers' organization has been found to increase market participation of households because it improves the capabilities of farmer production and marketing [31]. In this study, we assumed that membership of a farmer organization positively influenced both the probability of market participation and the quantity of rice sold among smallholder farmers in Myanmar.

\subsubsection{Total Production of Rice}

The total production of rice was measured in kilograms of rice produced. Smallholder farmers try to increase rice production and receive more income by selling the surplus amounts of rice. Ref. [32] concluded that households with semi-commercial farms would first produce for household consumption and sell the surplus. According to Martey et al. [27], an increase in the production of cassava was observed to increase farmer market participation in Ghana. Therefore, the total production of rice was hypothesized to positively influence both the volume of rice sold and the decision to participate in the market among smallholder farmers.

\subsubsection{Household Income}

Household income was captured as a continuous variable (Kyats) in Myanmar currency. Getahun [33] found that the high income generated by the fruit sector was an important motivational 
factor for households to participate in the market. This finding concurs with that of Gani and Hossain [34] who reported that farmers' decisions on market entry are significantly related to the amount of farm income. In this study, we also assumed that an indeterminate relationship between household income and the decision to participate in the market among smallholder farmers.

\subsubsection{Access to Roads}

Access to roads was used as a dummy variable in this study area. Getahun [33] found that the nearer to the main road, the better the farmers' access to market information and transportation. Another finding on commercialization of smallholders in Ethiopia by [35] noted that proximity to all-weather road encourages market orientation due to its effect of reducing marketing costs. Therefore, access to roads was posted as a factor that positively influenced both the volume of rice sold and the decision to participate in the market among smallholder farmers.

\subsubsection{Distance to Market}

The distance to the market was measured in kilometers. Mussema and Dawit [36] found that market participation among smallholder pepper producers in Silte and Aalaba of Ethiopia was negatively associated with distance to the market. In Ethiopia, it was reported that smallholder households who were away from market centers had lower market participation [36]. Hence, distance to the market was hypothesized to negatively influence the decision to participate and the quantity of rice sold to the market among smallholder rice farmers in Myanmar.

\subsubsection{Access to Extension Services}

Access to extension services was captured as a dummy variable in Myanmar. Smallholder farmers who have contact with the extension services may have a better understanding of new technologies such as high yielding varieties and other new farming practices, which encourage them to produce more and improve their livelihood. Siziba et al. [28] found access to extension training positively influenced the intensity of market participation among cereal producers in SSA. In this study, access to extension services was assumed to be positively related to the probability of market participation and volume of rice sold among smallholder rice farmers in Myanmar.

\subsubsection{Access to Market Information}

Access to market information was included as a dummy variable whether the household received information on the market prices prior to selling. Access to market information is important because it enables farmers to make more appropriate decisions on which market to sell to and when to sell the commodity. Farmers need comprehensive market information to be able to make the right decision on the amount of product to market and which price to receive. Therefore, this study hypothesized that access to market information positively influenced the decision of farmers to participate in the market.

\section{Result and Discussion}

\subsection{Demographic and Socioeconomic Characteristics of Farm Household in Relation to Market}

The sample of 150 farmers revealed that 100 farmers had participated in the rice market and 50 farmers did not. Tables 2 and 3 highlight the differences in demographic characteristics between market participants and non-participants. The average age among market participants was 48.31 , while the average age of non-participants was 52.98. The mean number of years spent in formal school by market participants was 7.01 while 2.46 years for non-market participants. This indicates that market participants have a higher education than non-market participants. The average yield of rice among market participants was $4394.27 \mathrm{~kg} / \mathrm{ha}$, while it was $3286.08 \mathrm{~kg} / \mathrm{ha}$ for non-market participants. This shows that the average yield or productivity of the rice market for market participants was higher than that of non-market participants. 
Table 2. Demographic characteristics of 150 smallholder rice farmers in Myothit Township in Magway Region, Central Dry Zone.

\begin{tabular}{|c|c|c|c|}
\hline \multirow{2}{*}{ Characteristics } & \multicolumn{2}{|c|}{ Mean } & \multirow[t]{2}{*}{ Overall } \\
\hline & $\begin{array}{l}\text { Market Participant } \\
\qquad(\mathrm{N}=100)\end{array}$ & $\begin{array}{l}\text { Non-Market Participant } \\
\qquad(\mathrm{N}=50)\end{array}$ & \\
\hline Age of household head (Years) & 48.31 & 52.98 & 49.86 \\
\hline $\begin{array}{l}\text { Education level of Household head } \\
\text { (Schooling years) }\end{array}$ & 7.01 & 2.46 & 5.49 \\
\hline Total production of Rice (Kilogram) & 4394.27 & 3286.08 & 4025.87 \\
\hline
\end{tabular}

The results reveal that $77 \%$ of the market participants were male, while $23 \%$ were female. Among non-market participants, the male and female sex ratio was $74 \%$ and $26 \%$ respectively. In terms of livestock ownership, $79 \%$ of the market participants were found to own livestock while $21 \%$ did not possess any livestock. Among non-market participants, 20\% raised livestock and 80\% did not. The result implies that market participants had more livestock than non-market participants.

The results also show that $56 \%$ of the market participants were engaged in farmer organizations while $44 \%$ were not. Among non-market participants, $32 \%$ were the membership to farmer organization while $68 \%$ were not. This means that market participants were involved in more organizational activities than non-market participants.

Table 3. Demographic characteristics of smallholder rice farmers in Myothit Township in Magway Region, Central Dry Zone.

\begin{tabular}{|c|c|c|c|c|c|}
\hline \multirow[t]{2}{*}{ Variable } & \multicolumn{2}{|c|}{$\begin{array}{l}\text { Market Participant } \\
\qquad \mathrm{N}=100\end{array}$} & \multicolumn{2}{|c|}{$\begin{array}{l}\text { Non-Market Participant } \\
\qquad \mathrm{N}=\mathbf{5 0}\end{array}$} & \multirow[t]{2}{*}{ Overall Freq } \\
\hline & $\%$ & Freq & $\%$ & Freq & \\
\hline \multicolumn{6}{|c|}{ Gender of Household } \\
\hline Male & 77.00 & 77 & 74.00 & 37 & 114 \\
\hline Female & 23.00 & 23 & 26.00 & 13 & 36 \\
\hline \multicolumn{6}{|c|}{ Membership to farmer Organization } \\
\hline Yes & 56.00 & 56 & 32.00 & 16 & 78 \\
\hline No & 44.00 & 44 & 68.00 & 34 & 72 \\
\hline \multicolumn{6}{|c|}{ Ownership of Livestock } \\
\hline Yes & 79.00 & 79 & 20 & 10 & 89 \\
\hline No & 21.00 & 21 & 80 & 40 & 61 \\
\hline \multicolumn{6}{|c|}{ Access to Roads } \\
\hline Yes & 43.00 & 57 & 6.00 & 3 & 46 \\
\hline No & 57.00 & 43 & 94.00 & 47 & 104 \\
\hline \multicolumn{6}{|c|}{ Access to Extension Services } \\
\hline Yes & 83.00 & 83 & 18.00 & 9 & 92 \\
\hline No & 17.00 & 17 & 82.00 & 41 & 58 \\
\hline \multicolumn{6}{|c|}{ Access to Market Information } \\
\hline Yes & 58.00 & 58 & 10.00 & 5 & 63 \\
\hline No & 42.00 & 42 & 90.00 & 45 & 87 \\
\hline
\end{tabular}

Among the interviewees, $43 \%$ of market participants said that they can use good roads to go to the market while only $6 \%$ of non-market participants were able to use good roads. This implies that road condition to access the market is a very important factor in the decision of market participation. In addition, $83 \%$ of the market participants had access to extension services while $17 \%$ were not able to access extension services. Among non-market participants, $18 \%$ had access to extension services while 
$82 \%$ of had no access to extension services. This illustrates that the market participants had better access to extension services than non-market participants.

Regarding access to market information, $58 \%$ of market participants received market information while $42 \%$ did not. Among non-market participants, $10 \%$ received market information while $90 \%$ did not. This implies that market participants received more market information compared to non-market participants.

\subsubsection{Factors that Determine the Decision by Smallholder Farmers to Participate in the Market}

The results in Table 4 highlight the factors that influenced the probability of participation in the rice market among small farmers in Myothit Township of Magway Region of Central Dry Zone. The first equation of the Heckman two-stage model showed that education level of household, total production of rice, road condition, and access to extension services were all significant at a $5 \%$ level.

Table 4. Factors that determine the decision by smallholder farmers to participate in the market. Note: $* * *, * *,{ }^{*}$ Indicate significance at 1, 5, and 10\% level, respectively.

\begin{tabular}{ccc}
\hline Variables & Coefficient & Std. Err \\
\hline Age of Household Head & 0.0012 & 0.0333 \\
Educational Status of Household Head & $0.4440^{* *}$ & 0.1559 \\
Total Production of Rice & $0.0004^{* *}$ & 0.0002 \\
Membership to Farmer organization & -0.2560 & 0.6471 \\
Ownership of Livestock & 1.0034 & 0.6428 \\
Access to Roads Condition & $1.9279^{* *}$ & 0.9324 \\
Access to extension & $1.3674^{* *}$ & 0.6068 \\
Access to Market Information & 0.5440 & 0.7852 \\
Constant & $-5.3725^{*}$ & 2.1014 \\
Mills Lambda & $-11.6545^{*}$ & 6.9902 \\
Rho & -1.0000 & \\
Sigma & 11.6545 & \\
\hline
\end{tabular}

Education level of the household head was positively related to the probability of a household's market participation and it was also significant at a 5\% level. The positive relationship implies that the increased education level of the household heads enables access to more information and new opportunities in various markets for their product. This means that the education level of household head is very important in enhancing market participation rate as it enables to acquire the new ideas and modern techniques of agricultural production and therefore increase the market surplus.

The coefficient of the total production of rice was positive and statistically significant at a $5 \%$ level. This might be an indication that increased market participation is also a function of rice productivity. Higher production of rice could drive market participation because farmers with high productivity have a surplus to sell in the market. This finding is consistent with the finding of Mather et al. [37] in which the researcher found that higher outputs increased the likelihood of market participation because it enables households to have a marketable surplus. This implies that participation of farmers in the market is higher when their total production of rice increased.

Access to better road conditions showed a positive impact on the probability of a household's market participation and it was significant at a $5 \%$ level. This result reveals that smooth movement of goods from rural areas to urban areas due to better road condition influences market participation. Good road infrastructures facilitate the transport of agricultural products from farm to market.

These results indicate that the coefficient of access to extension services was statistically significant and positively related with a household's market participation. The positive impact means that extension workers usually support new technologies and market information that enhances farmer knowledge and provides a variety of market opportunities and therefore extension services encourage farmer participation in the rice market. 


\subsubsection{Factors Affecting the Volume of Rice Sold by Smallholder Farmers in the Market}

The results in Table 5 underline the factors that have influenced the volumes of rice sold in the market among smallholder farmers through the second step equation of the Heckman two-stage model. The second step equation showed that household size, total production of rice, price of rice, membership to farmer organization, access to roads, distance to market, access to extension services, and access to market information were all statistically significant at below a 10\% probability level.

Household size indicated a negative influence on the quantity of rice sold in the market and statistically significant at an even $1 \%$ level. This negative coefficient illustrates that as the household size increased, the quantity of rice sold would decrease. Therefore, large households in rural areas would have fewer agricultural products for the market. Siziba et al. [28] stated that households with large family sizes fail to produce a marketable surplus beyond their consumption needs.

Table 5. Factors affecting the volume of rice sold by smallholder farmers in the market. Note. ${ }^{* * *}{ }^{* *}, *$ Indicate significance at 1, 5, and 10\% level, respectively.

\begin{tabular}{ccc}
\hline Variables & Coefficient & Std. Err \\
\hline Age & -0.1154 & 0.1338 \\
Educational Status & $0.7847^{* * *}$ & 0.5415 \\
Household Size & $-3.4217^{* * *}$ & 0.9757 \\
Total Produce of Rice & $0.0016^{* * *}$ & 0.0003 \\
Market Price of Rice & $0.0045^{*}$ & 0.0022 \\
Total Income & -0.0333 & 0.0490 \\
Ownership Livestock & $-7.6569^{*}$ & 3.0392 \\
Member of Farmer Organization & $7.0836^{* *}$ & 2.6137 \\
Road Condition & $4.1581^{* *}$ & 2.5545 \\
Distance to Market & $-1.8823^{* * *}$ & 0.5711 \\
Access to Extension & $11.7751^{* * *}$ & 3.5663 \\
Access to Market information & $6.5972^{* *}$ & 2.7813 \\
Constant & $60.3774^{* * *}$ & 16.8593 \\
\hline
\end{tabular}

The total production of rice had a positive impact on the ratio of market rice sales and it was statistically significant. The positive sign implies that the proportion of rice sold in the market would be higher if the farmers increase rice production. This could be explained by a factor that small householder farmers with more rice production would have more surplus to sell to the market. This result was consistent with the findings of Reyes et al. [38] which revealed that farmers with greater production had more surpluses they could sell.

The price of rice had a significant effect on the rice sales volume of farmers. The positive relationship reveals that the probability of selling of rice is higher when the market price of rice is high. The results of this study pointed out that higher market prices will enhance the farmer willingness to produce more, increasing the proportion of rice to be sold in the market by smallholder farmers. Olwande and Mathenge [25] also showed that farmers tend to sell more quantities of maize when the market price is higher.

The coefficient of membership of a farmer organization indicated a positive influence on the quantity of rice sold in the market and was significant at a $1 \%$ level. The results can be explained by the fact that farmer organizations play a role in social networks that enable farmers to access information and reduces fixed transaction costs. This indicates that membership of a farmer organization improves farmer knowledge of rice cultivation technologies and provides information about the output market and consequently increasing the profit.

Ownership of livestock had a negative impact on the quantity of rice sold in the market. The negative result of ownership of livestock indicates that an increase in livestock production will reduce the rice production. The result shows that if a household has livestock, the household members will need to share time and money with the livestock for feeding them and taking care of the livestock. 
In consequence, they will have less production surplus to sell in the market. They might need to borrow money or sell the livestock to meet the household consumption needs. On the other hand, farmers who own insufficient land for crop production may have a negative impact on their marketed surplus because they need to specialize in livestock breeding.

The distance to the market had a significantly negative influence on the quantity of rice to be sold in the market. This result illustrates that the longer the distance to market, the less the proportion of rice will be marketed. According to Martey et al. [27], distance to market is an indicator of travel time and increased transportation cost. Omiti et al. [11] stated that the quantities of output sold was influenced by the distance to the market. Therefore, the larger the distance to the market, the lower the amount of their products that the farmers sell in the market and they instead sell their products at the farm gate.

Access to extension services positively influences the quantity of rice to be sold in the market and it was statistically significant at $1 \%$ level. The positive relationship means that extension services usually provide information on market availability and improved varieties that enhance the farmer's knowledge of production. The results demonstrate the importance of improved technology and support for services in promoting rice sales in the market. This outcome is in line with Apind et al. [39] that the coefficient of extension services was positive and significantly influenced the quantity of rice sold among smallholder rice farmers.

The coefficient on access to market information showed a positive effect on the quantity of rice to be sold in the market and was significant at a $5 \%$ level. The positive outcome of market information implies that farmers who have access to market information are likely to sell their products. This result shows that access to market information would help improve farmer knowledge of the market and assist in planning on whether to sell rice in the market as well as the proportion of rice sales to the market. This infers that access to market information will lead to increased productivity with a high marketable surplus.

\section{Conclusions and Policy Recommendation}

\subsection{Summary of Results and Conclusion}

Marketing of agriculture product plays a critical role in meeting the overall goals of sustainable agriculture, food security, and poverty alleviation, particularly among smallholder farmers in rural areas. This study found that the market participation and sales ratio of smallholder rice farmers are constrained by several factors, such as socioeconomic, technological, and institutional factors, and market factors. Smallholder farmer market participation for rice was affected by factors such as education level, total produce of rice, road condition, and access to extension services. Smallholder rice farmers with a low level of education need to be empowered with the relevant marketing skills and knowledge through training programs that can be provided by extension services. In addition, working on tackling the factors related to market entry and participation of smallholders in the rice market will help to improve the rice sector, enhancing rural income and the livelihood of rural farmers.

The results also revealed that once a smallholder farmer decides to enter the market, household characteristics and farmer endowments are the key factors that influence how much to sell in the market. Household size, total produce of rice, price of rice, membership of farmer organization, ownership of livestock, distance to market, access to extension services, and access to market information were found to have significant influences on the level of market participation. Since rice production is directly linked to the farmer's income, its productivity should be improved. In addition to the demographic factors, such as age and education level, this study is different from previous studies in that it takes into account both market factors and management factors. The outcome of this study showed that most of these factors are important variables for market participation. In light of these findings, further research is required that looks more deeply into the relationship between market participation, the quantity sold, and household food security. 


\subsection{Policy Recommendation}

Through this study, we can provide important policy implications as these variables have a significant effect on the volume of sales and market participation. Agricultural production and productivity of smallholder farmers may not be naturally improved by giving priority to improving the rural infrastructures such as transportation, roads, and so forth. Each variable which affects rice farmer market activities requires different policies. It would be more effective if the government provides balanced policies on smallholder rice farmers, referring to the outcome of this research.

Moreover, the government should focus on follow-up activities in rice marketing policy, not only enhancing accessibilities to market for the smallholder rice farmers, so that rice sales and the market participation of farmers can develop. This can be achieved through institutional supports as well as agricultural technological innovation supports. In a big frame, the central government and the local government need to put efforts to enhance the ongoing investments in public facilities such as improved roads, irrigation schemes, telecommunications, and markets for agricultural inputs and outputs.

The results from this study support the United Nations' 2030 Agenda for Sustainable Development. Goal 2.3 aims to double the income of smallholder farmers by 2030 through information provision and market participation [40]. Based on the results of this study, the following five policy proposals can be made to achieve the objectives of the United Nations' 2030 Agenda for Sustainable Development: (1) Strengthening management, control, and knowledge provision on market trend information; (2) Promoting innovation related to new commercialization platforms; (3) Strengthening official dialogue channels between government and private sector; (4) Capacity building of the business sector with technical services; (5) Improving infrastructure, equipment, and agricultural management.

This study suggests directions for Myanmar government and the local governments to increase market participation and the income of smallholder rice farmers. From the perspective of the public sector, not only establishing balanced policies for the small-scale farmers but implementing and managing them in an appropriate way will induce agricultural development, hopefully contributing to poverty reduction, food security, and economic development in Myanmar. In recent years, agricultural management has faced new scenarios such as the development of new varieties, the rapid development of ICT and IOT. It is becoming more important to focus on the extent to which added value can be created rather than simply increasing output. In future research, it is necessary to examine the effects of technological development on farmer participation in the market, which is not covered in this study, and the innovative factors that influence added value.

Author Contributions: S.H.L. and N.N.K. identified research questions and made the statistical analysis; N.N.K. and S.A. wrote the paper.

Funding: There is no funding for this research.

Acknowledgments: The authors would like to thank the editors and anonymous referees for the constructive feedback and suggestions that have improved this article.

Conflicts of Interest: The authors of this research declare no conflict of interest.

\section{References}

1. Reardon, T.; Barrett, C.B. Agroindustrialization, globalization, and international development: An overview of issues, patterns, and determinants. Agric. Econ. 2000, 23, 195-205.

2. Timmer, C.P. A model of price marketing margin in Indonesia. Food Resenen Inst. Study 1974, 13, $145-167$.

3. World Bank Agriculture for Development. World Development Report 2008; World Bank: Washington, DC, USA, 2008.

4. Key, N.; Sadoulet, E.; Janvry, A.D. Transactions costs and agricultural household supply response. Am. J. Agric. Econ. 2000, 82, 245-259. [CrossRef]

5. Poole, N. Smallholder Agriculture and Market Participation; Practical Action Publishing: Rugby, UK, 2017. 
6. Dorosh, P.; Haggblade, S. Growth linkages, price effects and income distribution in sub-Saharan Africa. J. Afr. Econ. 2003, 12, 207-235. [CrossRef]

7. Magingxa, L.L.; Kamara, A.B. Institutional perspectives of enhancing smallholder market access in South Africa. In Proceedings of the 41st Annual Conference of the Agricultural Economic Association of South Africa, Pretoria, South Africa, 2-3 October 2003.

8. Eyzaguirre, P.; Grum, M.; Maundu, P.; Vodouhe, S.R.; Johns, T.; Onian'go, R.; Kakuramatsi-Kikafunda, J.; Ndossi, G.D.; Guiro, A.T. Dietary Diversity: Linking Traditional Food and Plant Genetic Resources to Rural and Urban Health in Sub-Saharan Africa; Technical Report; Via dei Tre Denari 472/a 00057; Bioversity International: Maccarese, Italy, 2006; pp. 1-36.

9. Torero, M. A framework for Linking Small Farmers to Markets. Presented at the IFAD Conference on New Directions for Smallholder Agriculture, Rome, Italy, 24-25 January 2011.

10. Makura, M.N.; Kirsten, J.; Delgado, C. Transactions Costs and Smallholder Participation in the Maize Market in the Northern Province of South Africa. Integrated Approaches to Higher Maize Productivity in the New Millennium; No. 338.16 FRI; CIMMYT: Nairobi, Kenya, 2002.

11. Omiti, J.; Otieno, D.; Nyanamba, T.; McCullough, E. Factors influencing the intensity of market participation by smallholder farmers: A case study of rural and peri-urban areas of Kenya. Afr. J. Agric. Resour. Econ. 2009, 3, 57-82.

12. Asfaw, S.; Shiferaw, B.; Simtowe, F.; Muricho, G.; Abate, T.; Ferede, S. Socio-economic Assessment of Legume Production, Farmer Technology Choice, Market Linkages, Institutions and Poverty in Rural Ethiopia: Institutions, Markets, Policy and Impacts Research Report No. 3. Field Crops Res. 2010, 36, 103-111.

13. Gyau, A.; Mbugua, M.; Oduol, J. Determinants of participation and intensity of participation in collective action: Evidence from smallholder avocado farmers in Kenya. J. Chain Netw. Sci. 2016, 16, 147-156. [CrossRef]

14. Al-Hassan, R.M.; Sarpong, D.B.; Mensah-Bonsu, A. Linking Smallholders to Markets; International Food Policy Research Institute, Ghana Strategy Support Program: Washington, DC, USA, 2006.

15. Lowder, S.K.; Skoet, J.; Raney, T. The number, size, and distribution of farms, smallholder farms, and family farms worldwide. World Dev. 2016, 87, 16-29. [CrossRef]

16. Vēveris, A. Analysis of the Cost Level and Production Efficiency at Agricultural Farms of Different Size. In Economic Science for Rural Development Conference Proceedings; Latvian University of Agriculture, Faculty of Economics: Jelgava, Latvia, 2009.

17. World Bank. Myanmar-Analysis of Farm Production Economics (English); World Bank Group: Washington, DC, USA, 2016.

18. Department of Planning (DOP); Ministry of Agriculture, Livestock and Irrigation (MOALI). Myanmar Agriculture at a Glance 2016; MOALI: Nay Pyi Taw, Myanmar, 2016.

19. Department of Agricultural Land Management and Statistics (DALMS); Ministry of Agriculture, Livestock and Irrigation (MOALI). Report of Land Utilization (2015-2016); MOALI: Myothit Township, Myanmar, 2016.

20. Department of Agriculture (DOA). Myothit Rice Production Report (2015-2016); MOALI: Myothit Township, Myanmar, 2016.

21. Heckman, J. Sample Selection Bias as a Specification Error. Econometric 1979, 47, 153-161. [CrossRef]

22. Puhani, P. The Heckman correction for sample selection and its critique. J. Econ. Surv. 2000, 14, 53-68. [CrossRef]

23. Bushway, S.; Johnson, B.D.; Slocum, L.A. Is the magic still there? The use of the Heckman two-step correction for selection bias in criminology. J. Quant. Criminol. 2007, 23, 151-178. [CrossRef]

24. Tauchmann, H. Consistency of Heckman-type two-step estimators for the multivariate sample-selection model. Appl. Econ. 2010, 42, 3895-3902. [CrossRef]

25. Olwande, J.; Mathenge, M.K. Market Participation among Poor Rural Households in Kenya; Tegemeo Institute of Agricultural Policy and Development: Foz do Iguaçu, Brazil, 2011.

26. Lubungu, M.; Chapoto, A.; Tembo, G.; Lusaka, Z. Smallholder Farmers Participation in Livestock Markets: The Case of Zambian Farmers; Indaba Agricultural Policy Research Institute: Lusaka, Zambia, 2012.

27. Martey, E.; Al-Hassan, R.M.; Kuwornu, J.K. Commercialization of smallholder agriculture in Ghana: A Tobit regression analysis. Afr. J. Agric. Res. 2012, 7, 2131-2141.

28. Siziba, S.; Nyikahadzoi, K.; Diagne, A.; Fatunbi, A.O.; Adekunle, A.A. Determinants of cereal market participation by sub-Saharan Africa smallholder farmer. J. Agric. Environ. Stud. 2011, 2, 180-193. 
29. Komarek, A. The determinants of banana market commercialisation in Western Uganda. Afr. J. Agric. Res. 2010, 5, 775-784.

30. Barrett, C.B. Smallholder market participation: Concepts and evidence from eastern and Southern Africa. Food Policy 2008, 33, 299-317. [CrossRef]

31. Bahta, S.; Bauer, S. Policy options for improving market participation and sales of smallholder crop producers: A case study of the Free State Province of South Africa. Afr. J. Agric. Res. 2012, 7, 3525-3533. [CrossRef]

32. Jari, B. Institutional and Technical Factors Influencing Agricultural Marketing Channel Choices amongst Smallholder and Emerging Farmers in the Kat River Valley. MSc Agricultural Economics Thesis, University of Fort Hare, Alice, South Africa, 2009.

33. Getahun, K.; Eskinder, Y.; Desalegn, A. Determinants of smallholder market participation among banana growers in Bench Maji Zone, southwest Ethiopia. Int. J. Agric. Policy Res. 2017, 5, 169-177.

34. Gani, O.; Hossain, E. Market participation decision of smallholder farmers and its determinants in Bangladesh. Ekon. Poljopr. 2015, 62, 163-179. [CrossRef]

35. Getahun, K. Profitability analysis and determinants of fruit tree based agroforestry system in Wondo District, Ethiopia. Afr. J. Agric. Res. 2015, 10, 1273-1280.

36. Mussema, M.; Dawit, A. Red pepper marketing in Siltie and Alaba in SNNPRS of Ethiopia: Factorolwas affecting households' marketed pepper. Int. Res. J. Agric. Sci. Soil Sci. 2012, 2, 261-266.

37. Mather, D.L.; Boughton, D.; Jayne, T.S. Smallholder Heterogeneity and Maize Market Participation in Southern and Eastern Africa: Implications for Investment Strategies to Increase Marketed Food Staple Supply; Department of Agricultural, Food, and Resource Economics and Department of Economics, Michigan State University: East Lansing, MI, USA, 2011.

38. Reyes, B.; Donovan, C.; Bernsten, R.; Maredia, M. Market participation and sale of potatoes by smallholder farmers in the central highlands of Angola: A Double Hurdle approach. In Proceedings of the International Association of Agricultural Economists (IAAE) Triennial Conference, Foz do Iguacu, Brazil, 18-24 August 2012.

39. Apind, B.O.; Lagat, J.K.; Bett, H.K.; Kirui, J.K. Determinants of small-holder farmers' extent of market participation: Case of rice marketing in Ahero irrigation scheme, Kenya. J. Econ. Sustain. Dev. 2015, 6, 154-160.

40. United Nations. Transforming our world: The 2030 agenda for sustainable development. In Resolution Adopted by the General Assembly; United Nations: New York, NY, USA, 2015. 